\title{
AINDA EXISTE ESPAÇO PARA O AMÁLGAMA NA ODONTOLOGIA?
}

Denise Cerqueira Oliveira

Doutora em Dentística. Professora Titular e Vice-presidente do Grupo Brasileiro de Professores de Dentística.

denisecq@gmail.com

O amálgama é um dos materiais mais longevos da Odontologia, e por mais de 160 anos vem sendo utilizado como material restaurador. Em 1895, Black, deu uma grande contribuição a este material, com suas pesquisas, e a partir daí, apareceu a primeira liga de fase dispersa, o Dispersalloy, nos anos sessenta, com excelentes resultados clínicos, pelas melhorias nas suas propriedades físicas e mecânicas que aumentaram a sua durabilidade.

Em 1956, observamos a ocorrência de uma das grandes tragédias da humanidade, o "Desastre de Minamata", onde uma indústria de plástico, ao despejar criminosamente por quase 30 anos, 27 toneladas de mercúrio (Hg) na Baía de Minamata, no Japão, causou a morte de 900 pessoas e lesões graves em mais de 2200. Isto deflagrou um movimento mundial para banir o uso do mercúrio no mundo e, em 2013, no Japão, foi assinada a Convenção de Minamata por representantes de mais de 140 países. Foi acordado que até 2020 dever-se-ia eliminar o $\mathrm{Hg}$ em vários materiais, tais como termômetros, medidores de pressão sanguínea, lâmpadas fluorescentes, entre outros.
As restaurações de amálgama não foram atingidas por esta proibição, mas o tratado sugeriu algumas disposições relativas à diminuição gradual de seu uso, sem exigir medidas proibitivas ou prazo de banimento, já que nenhuma pesquisa científica de alta confiabilidade foi publicada comprovando que o seu uso na cavidade oral possa levar a qualquer doença sistêmica.

Para discutir as questões relacionadas à utilização e ao ensino do amálgama dental, dois eventos de grande importância foram realizados sobre o assunto: um Simpósio na USP, em $2014^{1,2}$; e o Simpósio realizado pelo Grupo Brasileiro de Professores de Dentística (GBPD), em 201533. Compareceram além de professores de Faculdades de Odontologia de todo o Brasil, profissionais da área pública e privada e representantes de entidades de classe. Os resultados de ambos podem ser resumidos, pela constatação que não existe, ainda, um material restaurador capaz de substituir totalmente o amálgama, por suas qualidades de desempenho clínico, com maior longevidade e custo significativamente menor que $\circ$ das resinas compostas, e concluíram que o Amálgama deveria permanecer como conteúdo de 
ensino de graduação, por apresentar propriedades únicas como um excelente selamento marginal, e por ter uma indicação importante para a promoção da saúde oral. No entanto, deve-se sempre optar por cápsulas pré-dosadas, e dar orientação segura quanto aos cuidados referentes à restauração e gerenciamento dos resíduos.

Sabemos que as ações de prevenção levaram a uma diminuição das lesões de cárie e, isto, aliadas às melhorias das resinas compostas que tem a grande vantagem de ser um material estético, têm diminuído significativamente a procura pelo amálgama dental, já que o próprio paciente não aceita com facilidade este material. No entanto, a Dentística Restauradora é uma especialidade da área da saúde que se fundamenta em procedimentos com embasamento científico. A indicação de um procedimento não pode estar pautada em "modismos" que, muitas vezes, podem não se constituir em benefício para a saúde do paciente.

Assim, tanto a resina quanto $\circ$ amálgama são alternativas de escolha. A formação de profissionais deve levar a uma visão preventiva em relação à saúde bucal e a educação de pacientes, para que eles saibam como agir para preservar os dentes ao longo da vida. $O$ bom dentista sabe que nada substitui o esmalte e a dentina natural, e os materiais à nossa disposição deveriam ser utilizados apenas para melhorar a saúde e autoestima dos nossos pacientes.

Futuramente, as empresas conseguirão um material biocompatível, estético, adesivo, de baixo custo e grande durabilidade, com todas as propriedades mecânicas pertinentes ao amálgama que aí, então, poderá se aposentar com a certeza do dever cumprido.

\section{REFERÊNCIAS}

1. Ballester RY. Toxicidade do mercúrio e proteção ambiental. Anais Simpósio Amálgama Dental. 2014; São Paulo: USP, p. 3.

2. Gonçalves SEP. Amálgama Dental: qual o futuro? Devemos continuar ensinando amálgama? Braz Dent Sci. 2014;18(1):1.

3. Alcântara ICG, Azevedo PVR, Machado CT, Dantas EDV, Morais JF. O futuro do amálgama na prática odontológica: $\bigcirc$ que o clínico precisa saber. Rev Tecno \& info. 2015;2(2):3241. 